\title{
Kültürel Farklılıkların Yönetimi Sürecinde Kültürel Zekânın Etkinliği
}

\author{
Effectiveness of Cultural Intelligence Through Managing Cultural Differences
}

\author{
Nur KULAKOĞLU DILEK*, Cafer TOPALOĞLU** \\ *Arş.Gör., Batman Üniversitesi, Turizm İşletmeciliği ve Otelcilik Yüksekokulu, 72160, Batman. \\ E-posta: nurkulakoglu@hotmail.com \\ **Doç.Dr., Muğla Sıtkı Koçman Üniversitesi, Turizm Fakültesi, 48170, Muğla. \\ E-posta: cafertopaloglu@yahoo.com
}

\author{
MAKALE BILGILER \\ Makale işlem bilgileri: \\ Gönderilme tarihi: 24 Mart 2016 \\ Birinci düzeltme: 20 Haziran 2016 \\ İkinci düzeltme: 13 Temmuz 2016 \\ Kabul: 21 Temmuz 2016 \\ Anahtar sözcükler: Kültürel farklılı- \\ ların yönetimi, Kültürel zekâ, Yapısal \\ eşitlik modeli, Seyahat acentaları.
}

\section{ARTICLE INFO}

Article history:

Submitted: 24 March 2016

Resubmitted: 20 June 2016

Resubmitted: 13 July 2016

Accepted: 21 July 2016

Key words: Management of cultural differences, Cultural intelligence, Structural equation modeling, Travel agencies.

\begin{abstract}
$\ddot{O Z Z}$
Çalışmanın temel amacı, A grubu seyahat acentaları yöneticileri üzerinde kültürel zekânın önemini ve kültürel farklıııkların yönetilebilmesi sürecindeki etkisini irdelemektir. Bu bağlamda çalıșmada, yazındaki çalıșmalardan hareketle turizm sektörü için çıkarımsal olarak söylenebilen kültürel zekâ-kültürel farklılık yönetimi ilişkisi seyahat acentaları yöneticileri açısından sınanmaktadır. Bu sınama neticesinde, seyahat acentası yöneticilerinin kültürel farklııkları yönetme süreçlerinde kültürel zekâ kullanımlarını ortaya koymak, çalışmanın önemini oluşturmaktadır. Bu önem ve amaç doğrultusunda i̇stanbul, İzmir, Antalya ve Muğla illerinde faaliyet gösteren A grubu seyahat acentalarının yerli ve yabancı toplamda 310 yöneticisinden anket tekniğiyle elde edilen veriler yapısal eşitlik modeli ile analiz edilerek yorumlanmıştır. Elde edilen sonuçlara göre, yöneticilerin kültürel zekâ düzeyi ile kültürel farklılıkların yönetilmesi arasında pozitif yönlü bir ilişki olduğu belirlenmiştir. Yöneticilerin kültürel zekâ düzeyi arttıkça, kültürel farklılıkların yönetiminin de güçlendiği belirlenmiştir.
\end{abstract}

\section{GíRiş}

Günümüzde, küreselleşme her alanda kendini hissettirmekte ve çeşitli paradigma dönüşümlerine neden olmaktadır. İçinde bulunduğumuz yeni yüzyılda ülke sınırlarının ortadan kalkmasıyla, hayatın her alanında yaşanan büyük değişimler yalnız toplumların değil işletmelerin de

\footnotetext{
* Bu makale, Nur Kulakoğlu Dilek'in Muğla Sitkı Koçman Üniversitesi Sosyal Bilimler Enstitüsü'nde yazılan “Kültürel Farklılıkların Yönetimi Sürecinde Kültürel Zekânın Etkinliği: A Grubu Seyahat Acentaları Yöneticileri Üzerine Bir Alan Araştırması" başlıklı yüksek lisans tezinden derlenmiştir.
}

yapılarını, kültürlerini ve yönetim felsefelerini etkilemektedir. İşletmeler için artık sadece ulusal pazarda rekabet etmek doyurucu olmamakta, küresel pazarlara açılmak zorunluluk haline gelmektedir. Böylelikle, işletmeler de çok kültürlü örgütlere dönüşmeye ve evrilmeye başlamışlardir.

Genel olarak örgütlerde kültürel farklılıklar, farklı kültürel gruplardan gelen çalışanların oluşturduğu işgücü yapısı ile ortaya çıkmaktadır. Bu şekilde oluşan farklılıklar bireylerin algi, tutum ve davranışları üzerinde önemli rol oynamakta- 
dır (Seymen 2006: 298). Hofstede'in (1980) yapt1$\breve{g}$ g ampirik çalışmalar; ülkelerin birbirinden farklı kültürel dokularının, iş yaşamı üzerinde önemli etkiler yaratabileceğini ortaya koymuştur.

Kültürel farklılıkların yönetimi anlayışı, çalışanların yaratıcılıklarını geliştirmesi, işletmenin küresel çaptaki gelişmelere daha hızlı uyum sağlaması, bireysel ve örgütsel performansı artırması, işletmelerin rekabet gücünü yükseltmesi ve örgütsel bağlılığı artırması bakımından büyük öneme sahiptir (Mollica 2003; Ang vd. 2007; Gümüş 2009; Barutçugil 2011). Bu farklılıklardan en iyi şekilde yararlanmak, örgütte içsel bütünlüğü sağlamak, sinerji yaratmak, verimlilik ve inovasyonu arttırarak rekabet gücünü yükseltmek için birçok yönetim stratejisinden bahsedilmektedir. Kültürel farklılıkların etkin yönetimine yönelik bu stratejilere yazında ve uygulamada henüz çok yeni olan bir strateji daha eklenmiştir. Bu yönetsel strateji; farklı kültürden bir kişinin hareket, davranış, ses, mimik, ton ve vurgusunu, o kişiyle aynı kültürden olan insanlar gibi anlayabilmesi, değerlendirmesi ve yorumlaması olarak ifade edilen kültürel zekâ kavramıdır (Earley ve Mosakowski 2004: 139; Yeşil 2009: 123).

Bu bağlamda, turizm sektörünün uluslararası boyutta pek çok farklı kültürden insanı bir araya getiren bir zemin olduğu düşünüldüğünde, kültürel farklılıkları yönetebilmek adına kültürel zekânın sektör için büyük önem taşıdığı söylenebilir. Nitekim Arora ve Rohmetra da (2010: 217) kültürel zekânın önemine vurgu yapmakta ve işletmelerin, müşterileriyle ve çalışanları ile olan kültürlerarası etkileşimlerinde kültürel zekâdan yararlanmaları gerektiğini ifade etmektedir.

$\mathrm{Bu}$ çalışmanın temel amacı, A grubu seyahat acentası yöneticilerinin çalışma ortamındaki kültürel farklılıklara yönelik yönetim becerilerinin, çeşitli boyutlarını ortaya çıkarmak ve bu farklılıkların yönetimi sürecine, yöneticilerin kültürel zekâ düzeylerinin bir etkisi olup olmadığını tespit etmektir. Bununla birlikte, kültürel zekâ bileşenlerinin kültürel zekânın oluşumu üzerindeki etkisi ve kültürel farklılıkların yönetimi alt boyutları ile kültürel zekâ alt boyutları arasındaki ilişkiler de incelenmiştir. Çalışmanın son kısmında, kültürel farklılıkların etkin yönetilebilmesi için mevcut yönetim stratejilerine alternatif olan kültürel zekâ kavramının örgütlere etkisine değinilerek gelecek yıllarda yapılacak çalışmalara çeşitli önerilerde bulunulmaya çalışılmıştır. Kültürel zekâ uluslararası yazında çalışılan bir konu olmakla birlikte, Türkiye'de özellikle turizmle ilişkili kısıtlı yayın olması nedeniyle çalışmanın, teorik ve pratik anlamda hem yazına hem de turizm işletmelerine katkı sağlayacağı düşünülmektedir.

\section{KURAM}

\section{Kültürel Farklılıkların Yönetimi ve Kültürel Zekâ}

Kültürel farklılıkların yönetimi; “Uluslararası, çokuluslu ve küresel örgütlerde çalışan, uluslararası operasyonlarda yer alan veya uluslararası işgücünü oluşturan; farklı geçmişleri, ilgileri, inançları, beklentileri ve çalışma biçimleri olan; bireylerin veya grupların yönetim stratejilerinin, politikalarının, girişimlerinin, eğitim ve geliştirme faaliyetlerinin planlanması, uygulanması ve koordine edilmesi" şeklinde tanımlanmaktadır (Özbilgin 2005: 9). Kültürel bağlamda farklılıkları yönetmenin amacı tüm çalışanları ırk, cinsiyet, dil, din ya da milliyet gibi sosyal kimliklerin olumsuz etkilerinden kurtararak tüm yeteneklerini örgüt amaçları doğrultusunda kullanmalarına teşvik etmektir (Barutçugil 2011: 202).

Çok kültürlülüğü kavrayabilme ve onu yönetebilme yeteneği, günümüz iş dünyasının en önemli gerekliliklerinden biri olarak görülmektedir. Bu bağlamda, kültürel farklılıkları yönetme anlayışını kolaylaştıran birçok model ve teori ortaya atılmıştır. Bu teori ve modellerin ortak amacı, kültürel farklılıklardan en fazla avantaj sağlayacak şekilde stratejilerin geliştirilmesidir (Barutçugil 2011: 217). Çok kültürlü ortamlarda yöneticilerin kültürel farklılıkları nasıl yöneteceği konusunda tam anlamıyla bir görüş birliğinden bahsedilememekle beraber, birçok farklı yönetim stratejisi ortaya atılmıştır. Nahavandi ve Malekzadeh'e göre (1998), kültürel farklılıkların etkin bir şekilde yönetilebilmesi için birtakım başarı faktörleri (farklılık merkezli örgütsel politikalar, açık ve tutarlı işgören politikaları, herkes için adaletli olma, düzenli gözlem ve değerlendirme gibi) bulunmaktadır. Borham ve Wills 
(1992) ise yaptıkları araştırmada, farklı kültürlerden gelen bireylerin oluşturduğu örgütleri başarılı yönetmenin sırrını; bilinçli stratejiler oluşturmak, yeni durumlara uyum sağlayabilmek, farklı kültürlere karşı hassas olabilmek, çok kültürlü takımlarla çalışabilmek, dil yeteneğine sahip olmak, uluslararası farklılıkları anlayabilmek şeklinde özetlemektedirler (Ehtiyar 2003: 72).

Kültürel farklılıkların yönetiminde, çeşitli araştırmacılar tarafından ortaya atılan koşulların d1şında, diğer bazı unsurlar da oldukça önemli bir yere sahiptir. Bunlardan biri, örgüt içindeki kültürel farklılıkların yok sayılması yerine, etkili yönetim stratejileri ve davranışları ile desteklenmesi ve güçlü bir rekabet aracı olarak kullanılması gerekliliğidir. Buradan hareketle, örgüt içinde yer alan; özellikle yöneticiler olmak üzere her bir çalışanın, kültürle ilişkili birtakım yeteneklere sahip olması gerekmektedir (İşçi, Söylemez ve Kaptanoğlu 2013: 3). Akiş (2007) söz konusu yetenekleri; "Esneklik ve Yenilikçi Olma, Kültürel Adaptasyon (Kültürel Uyum), Uluslararası İş Bilgisi (Global Liderlik) ve Farkl Perspektiften Bakabilme" şeklinde özetlemektedir.

1960'tan sonra uluslararası yönetimde kültürel değerlerin ön plana çıkarak yönetsel boyutta önem kazanmasıyla birlikte, kültürel olarak farklı bireyler arasındaki farklılıkların farkında olma, farklılıkları kabul etme ve farklılıklara değer verme oldukça önem kazanmıştır. Bu bağlamda kültürel farklılıkların yönetilebilmesi için alternatif bir strateji olarak dikkat çeken "kültürel zekâ" kavramı ortaya çıkmıştır (Yeşil 2009: 120).

Kültürel zekâ (CQ), "kültürleri daha iyi anlamak, başka kültürlerden olan kişilerle karşılıklı iletişim konusunda daha fazla bilgi edinmek ve farklı kültürden olan kişiler hakkındaki düşüncelerimizin zamanla değişmesini sağlamak adına yetenekli ve esnek olmak" şeklinde ifade edilmektedir (Thomas ve Inkson 2004: 14). Kültürel zekâ; başka bir ülkeden, kültürden olan birisinin kendisine yabancı olan jest ve eylemleri yorumlayabilmesine olanak sağlayan bir yetenek ve beceridir (Gibson ve Dibble 2008: 232). Benzer bir tanım olarak kültürel zekâ kişinin, farklı kültürden bir kişinin hareket, davranış, ses, mimik, ton ve vurgusunu, o kişiyle aynı kültürden olan insanlar gibi anlayabilmesi, de- ğerlendirmesi ve yorumlaması olarak ifade edilmektedir (Earley ve Mosakowski 2004: 139).

Kültürel zekânın oluşumunu sağlayan birtakım bileşenlerin olduğu pek çok yazar tarafından ifade edilmektedir. Earley ve Ang (2003), Sternberg ve Detterman'ın (1986) çalışmasından uyarladıkları üstbilişsel, bilişsel, motivasyonel (güdüsel) ve davranışsal olmak üzere dört temel bileşeni içerisinde barındıran çok boyutlu bir model önermişlerdir (Aktaran: Ang ve Van Dyne 2008: 16). Kültürel zekâ, nitelik olarak dört farklı bileşenden oluşsa da bu dört bileşenin her biri birbiri ile ilişkilidir. Gerçek bir yönetsel etkinlik için, yöneticilerin bu dört kültürel zekâ yeteneğine de sahip olmaları gerekmektedir. Bu çalışmada Van Dyne, Ang ve Livermore (2010) tarafından ele alınan üst bilişsel, bilişsel, motivasyonel ve davranışsal kültürel zekâ boyutları üzerinde durulmuştur:

Üst bilişsel kültürrel zekâ; kültürel bilginin elde edilmesi ve kavranmasında bireyin kullandığ 1 birtakım zihinsel süreçleri ve bu süreçlerin kontrolünü ifade etmektedir (Şahin 2011: 83). Kişinin geçmişteki kültürel deneyimlerini kendi içinde analiz ederek ve değerlendirerek, gelecekteki kültürel etkileşimlerinde kolaylık sağlayabilmesidir. Bu bağlamda, üst bilişsel zekâsı yüksek olan kişilerin, kültürel bilgilerini değiştirebilmek, geliştirebilmek ve kültürel önyargılardan kurtulabilmek adına diğerlerine göre daha güçlü olduğu ifade edilmektedir (Thomas vd. 2008: 127; Ang ve Van Dyne 2008: 17).

Bilişsel kültürel zekâ; farklı kültürlerin dili, dini inançları, yasal ve ekonomik sistemleri, kültürel ve sosyal değerleri hakkında bilgilere sahip olmayı içermektedir (Ang ve Van Dyne 2008). Yüksek bilişsel zekâya sahip insanlar, kültürlerin birbirleriyle olan benzerlik ve farklılıklarını anlayabilme kapasitesine sahiptirler (Ang vd. 2007: 341; Yeşil 2010: 159).

Motivasyonel kültürel zekâ; farklı kişiler ile kültürel olarak etkileşim içerisinde olmayı gerektiren durumlarda, bireyleri bu yönde tetikleyen bir dürtü şeklinde tanımlanmaktadır (Templer vd. 2006: 154). Motivasyonel kültürel zekâsı yüksek olan kişiler, kültürel farklılıklara olan ilgilerinden dolayı, tüm enerji ve dikkatlerini kültürle- 
rarası durumlara kanalize ederek başarılı olabilmektedirler (Yeşil 2009: 124).

Davranışsal kültürel zekâ; bilişsel ve motivasyonel zekânın bir araya getirilerek 'gerçek dünya'ya uygulanabilmesi ile ilgilidir. Davranışsal kültürel zekâ, karşılaşılan durumun gerekliliğine uygun davranışın sergilenmesi anlamına gelmekte, baş- ka bir deyişle farklı kültürel durumlardaki farklı davranış becerilerini tanımlamaktadır (Earley ve Ang 2003: 81). Davranışsal kültürel zekâsı yüksek kişiler, sözel ya da sözel olmayan davranış yetenekleri doğrultusunda farklı kültürel ortamlara uygun davranış şekilleri (uygun dil kullanı$\mathrm{m} 1$, yüz ifadeleri, jest ve mimikler, ses tonu gibi) gösterebilmektedir (Ang ve Van Dyne 2008: 17).

Tablo 1. Kültürel Zekâ ve Kültürel Farklılıkları Yönetme Arasındaki İlişkiye Yönelik Çalışmalar

\begin{tabular}{|c|c|c|c|}
\hline Yazarlar & Kültürel Zekâ Tanımı & Kültürel Zekâ Bileşenleri & Sonuçlar/Uygulamalar \\
\hline $\begin{array}{l}\text { Earley (2002); } \\
\text { Earley ve Ang } \\
(2003)\end{array}$ & $\begin{array}{l}\text { Kişinin yeni kültürel şartlara etkin } \\
\text { bir şekilde uyum sağlama } \\
\text { yeteneğidir. }\end{array}$ & $\begin{array}{l}\text {-Bilişsel (Üst Bilişseli de } \\
\text { içeren) } \\
\text {-Motivasyonel } \\
\text {-Davranışsal }\end{array}$ & $\begin{array}{l}\text { Küresel iş ve } \\
\text { görevlendirmelerde başarı; } \\
\text { kültürel farklılıkları } \\
\text { yönetme; eğitim yöntemleri }\end{array}$ \\
\hline $\begin{array}{l}\text { Thomas ve Inkson } \\
\text { (2003) }\end{array}$ & $\begin{array}{l}\text { Kültürlerarası etkileşimin } \\
\text { temellerini anlamayı, duyarlı bir } \\
\text { yaklaşım geliştirmeyi ve farklı } \\
\text { kültürlerarası durumlarda etkin } \\
\text { uyum becerileri ve davranış } \\
\text { biçimleri oluşturma gerekliliğidir. }\end{array}$ & $\begin{array}{l}\text {-Farkındalık } \\
\text {-Bilgi } \\
\text {-Davranış Becerileri }\end{array}$ & $\begin{array}{l}\text { Kültürlerarası karar verme; } \\
\text { kültürlerarası iletişim; } \\
\text { kültürlerarası liderlik; çok } \\
\text { kültürlü takımlar; } \\
\text { uluslararası kariyer }\end{array}$ \\
\hline $\begin{array}{l}\text { Earley ve } \\
\text { Mosakowski (2004) }\end{array}$ & $\begin{array}{l}\text { Kişinin, farklı kültürden bir kişinin } \\
\text { hareket ve davranışlarını o kişiyle } \\
\text { aynı kültürdenmiş gibi anlayıp } \\
\text { yorumlayabildiği doğal bir } \\
\text { yetenektir. }\end{array}$ & $\begin{array}{l}\text {-Bilişsel } \\
\text {-Fiziksel } \\
\text {-Duygusal/ Motivasyonel }\end{array}$ & $\begin{array}{l}\text { Yeni ve farklı kültürlere } \\
\text { uygun davranış sergileme }\end{array}$ \\
\hline $\begin{array}{l}\text { Earley ve Peterson } \\
(2004)\end{array}$ & $\begin{array}{l}\text { Kişinin farklı kültürel ortamlarda } \\
\text { veya durumlarda gerçekleştireceği } \\
\text { faaliyetleri etkin bir şekilde yerine } \\
\text { getirebilme yeteneğidir. }\end{array}$ & $\begin{array}{l}\text {-Üst bilişsel/Bilişsel } \\
\text {-Motivasyonel } \\
\text {-Davranışsal }\end{array}$ & $\begin{array}{l}\text { Kültürlerarası öğrenim; çok } \\
\text { uluslu takımlar }\end{array}$ \\
\hline $\begin{array}{l}\text { Earley, Ang ve Tan } \\
\text { (2006) }\end{array}$ & $\begin{array}{l}\text { Kültürel bağlamda, kişinin yabancı } \\
\text { olduğu bir ortama başarılı bir } \\
\text { şekilde uyum sağlayabilme } \\
\text { yeteneğidir. }\end{array}$ & $\begin{array}{l}\text {-Kültürel stratejik düşünme } \\
\text {-Motivasyon } \\
\text {-Davranış }\end{array}$ & $\begin{array}{l}\text { Küresel iş görevlendirmeleri; } \\
\text { küresel takımlar; küresel } \\
\text { liderlik }\end{array}$ \\
\hline Thomas (2006) & $\begin{array}{l}\text { Farklı kültürlerden insanlar ile } \\
\text { etkin etkileşime geçebilme } \\
\text { yeteneğidir. }\end{array}$ & $\begin{array}{l}\text {-Bilgi } \\
\text {-Farkındalık } \\
\text {-Davranış }\end{array}$ & Geliştirme; Değerlendirme \\
\hline Ang vd. (2007) & $\begin{array}{l}\text { Kültürel açıdan farklı ortamlarda } \\
\text { bireyin etkin bir biçimde yönetme } \\
\text { becerisidir. }\end{array}$ & $\begin{array}{l}\text {-Bilişsel } \\
\text {-Üst Bilişsel } \\
\text {-Motivasyonel } \\
\text {-Davranışsal }\end{array}$ & $\begin{array}{l}\text { Kültürel yargı ve karar } \\
\text { verme; kültürel uyum ve } \\
\text { görev performansı }\end{array}$ \\
\hline Thomas vd. (2008) & $\begin{array}{l}\text { Kişinin, üstbilişsel bilgi ve } \\
\text { yeteneklerine bağıı olarak } \\
\text { bulunduğu kültürel çevredeki } \\
\text { adaptasyonu, davranış biçimleri ve } \\
\text { seçimlerinden hareketle ortaya } \\
\text { çıkan karşılıklı etkileşime dayalı bir } \\
\text { sistemdir. }\end{array}$ & $\begin{array}{l}\text {-Kültürel Bilgi } \\
\text {-Kültürler arası yetenekler } \\
\text {-Kültürel } \\
\text {-Üst Bilişsel }\end{array}$ & $\begin{array}{l}\text { Kültürlerarası etkin iletişim } \\
\text { (Bireysel uyum, kişilerarası } \\
\text { ilişki geliştirme, iş ya da } \\
\text { görev performansı) }\end{array}$ \\
\hline
\end{tabular}

Kaynak: Thomas, Elron, Stahl, Ekelund, Ravlin ve Cerdin (2008). 


\section{ILGILI ÇALIŞMALAR}

İngilizce'de Cultural Intelligence (CI) ya da Individual's Cultural Quotient (CQ) olarak ifade edilen kültürel zekâ kavramı ilk kez P. Christopher Earley (London Business School) ve Elaine Mosakowski'nin (University of Colorado at Boulder) 2004'te Harvard Business Review'de yayınlanan makalesinde ortaya atılmıştır (Yeşil 2009: 123). Bireyin farklı kültürel ortamlarda etkin bir şekilde çalışabilme ve yönetebilme yeteneği olarak tanımlanan (Ang vd. 2007) kültürel zekâ üzerine yapılan çalışmalara bakıldığında konunun daha çok teorik düzeyde ele alındığ ${ }_{1}$, alan çalışmalarının da yapıldığı fakat yetersiz olduğu görülmektedir (Tablo 1).

Söz konusu çalışmalar, kültürel zekânın bir yetenek olduğu ve kültürel farklılıklara uyum, kültürlerarası iş yapabilme ya da küresel takımlar oluşturabilme adına önemini ortaya koymaktadır. Başka bir ifadeyle kültürel zekâ ve kültürel farklılıkları yönetme arasında pozitif yönlü bir ilişkinin olduğu vurgulanmaktadır. Bu bağlamda en dikkat çekici çalışma ise Ang vd. (2007) tarafından kültürel zekânın dört bileşeni ile kültürlerarası etkinliğin (kültürel yargı ve karar verme, kültürel uyum ve görev performansı) arasındaki olumlu ilişkiye vurgu yapılan çalışmadır.

Bu bağlamda, uluslararası boyutta çok farklı kültürlerden insanları bir araya getiren bir platform olarak düşünüldüğünde, kültürel zekânın turizm sektörü için büyük önem taşıdığı söylenebilir. Nitekim Arora ve Rohmetra da (2010: 217) söz konusu önemin altını çizmekte ve örgütlerin müşterileriyle olan kültürlerarası etkileşimlerinde kültürel zekâdan yararlanmaları gerektiğini ifade etmektedir. Bununla birlikte uluslararası turizm işletmelerinin kültürel olayları kavrayabilme, kendilerini dönüştürebilme ve kültürel farklılıkları içselleştirerek gelişim gösterebilmeleri adına kültürel zekânın gerekliliği üzerinde durulmaktadır. Özellikle farklı kültürel ortamlarda faaliyetlerini yürüten uluslararası zincir turizm işletmelerinin, küresel ekonomik yapı ve karmaşık iş ortamları ile baş edebilmeleri amacıyla çok kültürlü ve yaratıcı ekiplere yönelmeleri gerekmektedir. Bu gereklilik paralelinde; farklı kültürel kimliklere ait kişiler ile birlikte çalışa- bilen, kültürel zekâya ve kültürlerarası yönetim becerisine sahip yöneticilere de ihtiyaç duyulmaktadır. Öyle ki, kültürel zekânın uluslararası liderlik potansiyelinin belirleyicisi olduğu (Kim ve Van Dyne 2011; Rockstuhl vd. 2011) ve kültürlerarası liderlik etkinliğini artırdığı çeşitli çalışmalarla bulgulanmıştır (Şahin 2011: 98; Şahin vd. 2012: 359). Bu çalışma da A grubu seyahat acentalarında çalışan yerli ve yabancı yöneticiler için, kültürel farklılıkları yönetme sürecinde kültürel zekânın önemli bir etken olup olmadığını ortaya koymak ve bu kapsamda alanyazındaki boşluğu doldurmak amaciyla gerçekleştirilmiştir. Böylelikle yazındaki çalışmalardan hareketle turizm sektörü için çıkarımsal olarak söylenebilen kültürel zekâ-kültürel farklılık yönetimi ilişkisinin sınanarak temellendirilmesi sağlanmış olacaktır.

\section{Araştırmanın Yapısal Modeli ve Hipotezlerin Oluşturulması}

Yapısal model, gizil değişkenler arasındaki nedensel ilişkileri belirleyen (Yılmaz 2004: 80), k1saca araştırmacının sınamak istediği modeldir. İngilizce adiyla Structural Equation ModelingSEM olarak adlandırılan Yapısal Eşitlik Modeli (YEM), gözlenen ve gözlenemeyen (gizil-latent) değişkenler arasındaki nedensel ilişkilerin sınanmasında kullanılan kapsamlı bir veri analiz tekniğidir (Şimşek 2007: 3). Yapısal eşitlik modellemesi uygulamaları, son yıllarda sosyal bilimler ve davranış bilimlerindeki önemi ve kullanım sıklığı gittikçe artan bir teknik olmuştur (Şimşek 2007: 1). YEM uygulamalarının temel özelliği tamamen teoriye dayalı olmalarıdır. Araştırmacıların çalışmaya başlamadan önce mutlaka teorik bir çerçeve oluşturmuş olmaları gerekmektedir. Diğer araştırma teknikleri için de geçerli olan; önceden belirlenmiş değişkenler arası ilişki örüntülerinin data tarafından doğrulanıp doğrulanmadığı sorgusu YEM çalışmaları için daha büyük öneme sahiptir. Bunun nedeni; YEM çalışmalarının genelde oldukça karmaşık ve spesifik hipotezlerin test edilmesinde kullanılmasıdır (Dursun ve Kocagöz 2010: 2).

Bu araştırma kapsamında toplam 13 adet hipotez test edilmiştir. Söz konusu hipotezlerin yapısal bir modele aktarılmasıyla birlikte, araştırmanın izleyeceği model Şekil 1'deki gibidir: 


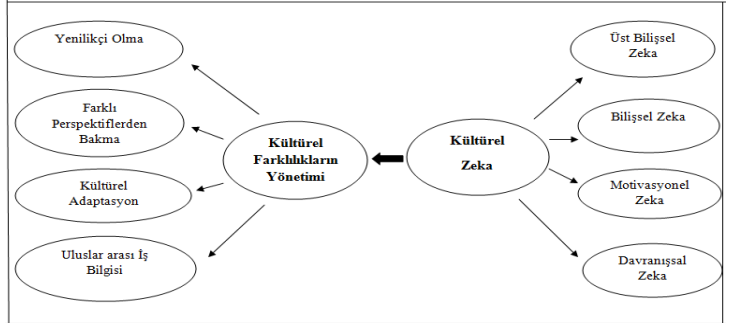

Şekil 1. Araştırmanın Temel Modeli

Şekil 1'deki yapısal modele göre, araştırmada kültürel zekânın her bir alt boyutunun kültürel zekânın oluşumu üzerinde etkisinin olup olmadığı̆, aynı şekilde kültürel farklılıkların yönetimi ile ilgili yöneticilerin sahip olması gereken birtakım becerilerin de kültürel farklılıkların yönetimi sürecini etkileyip etkilemediği test edilmiştir. Son olarak araştırmanın da temel konusunu oluşturan; yöneticilerin kültürel zekâ düzeyinin kültürel farklılıkların yönetimi sürecindeki etkisi incelenmiştir.

Şekil 1'deki araştırma modelinden hareketle, araştırmanın yöntemine ve kavramsal modeline yönelik aşağıdaki hipotezler oluşturulmuştur.

H1: Yöneticilerin üst bilişsel zekâ kullanımlarındaki artış kültürel zekânın oluşumunda artışa neden olur.

H2: Yöneticilerin bilişsel zekâ kullanımlarındaki artış kültürel zekânın oluşumunda artışa neden olur.

H3: Yöneticilerin motivasyonel zekâ kullanımlarındaki artış kültürel zekânın oluşumunda artışa neden olur.

H4: Yöneticilerin davranışsal zekâ kullanımlarındaki artış kültürel zekânın oluşumunda artışa neden olur.

H5: Yöneticilerin uluslararası iş bilgisine sahip olması kültürel farklılıkların yönetimini güçlendirir.

H6: Yöneticilerin kültürel adaptasyonunun güçlü olması kültürel farklılıkların yönetimini güçlendirir.

H7: Yöneticilerin farklı perspektiflerden bakabilme becerilerinin olması kültürel farklılıkların yönetimini güçlendirir.
H8: Yöneticilerin yenilikçi olma becerilerinin olması kültürel farklılıkların yönetimini güçlendirir.

H9: Yöneticilerin kültürel zekâları artarken kültürel farklılıkları yönetme becerileri de artar.

Hipotezlerin ilk dördü, kültürel zekâ bileşenlerinin kültürel zekâ oluşumuna olan etkisini ölçmek amaciyla, sonraki dört hipotez ise kültürel farklılıkların yönetimi bileşenlerinin kültürel farklılıkları yönetme becerisine olan etkisini ölçmek amacıyla tasarlanmıştır. Sonuncu hipotez ise genel olarak kültürel zekâ ve kültürel farkl1lıkları yönetme becerisi arasındaki ilişkiyi ortaya koymak amacıyla geliştirilmiştir.

Öyle ki, Ang vd. (2007) ve Van Dyne vd. (2010) yaptıkları çalışmada kültürel zekâ bileşenlerinden ve bu bileşenlerin kültürel zekânın oluşumuna olan etkisinden söz etmektedirler. Söz konusu etki çalışmanın ilk dört hipotezinin (H1 - H4) dayanak noktasını oluştururken; Akiş'in (2007) "Farklı Kültürlerde Liderlik Yapmak" adlı çalışmasında ortaya koymuş olduğu kültürel farklılıkları yönetme bileşenleri de çalışmanın diğer dört hipotezinin (H5 - H8) oluşturulmasında çıkış noktası olmuştur. Son hipotez ise (H9) yazındaki çalışmalardan hareket ile alanyazındaki boşluğu doldurmak amacıyla yazarlar tarafından oluşturulmuştur. Böylelikle konu ile ilgili hem turizm yazınında daha önce sınanmamış hipotezlerin sınanması, hem de yönetim alanyazınındaki boşluğun doldurulması sağlanmış olacaktır.

\section{YÖNTEM}

Araştırmanın temel sorusu, A grubu seyahat acentası yöneticilerinin kültürel zekâ düzeylerinin, kültürel farklılıkların yönetimi sürecinde etkili olup olmadığıdır. Bu temel soruya cevap bulabilmek için nicel araştırma yöntemlerinden anket tekniği tercih edilmiştir. Nicel araştırma yönteminin tercih edilmesinin en önemli nedeni, objektif değerlendirmelerle araştırma bulgularının geçerlilik ve güvenilirliğini sağlamaktır.

\section{Araştırmanın Evren ve Örneklemi}

Araştırmanın evrenini İstanbul, İzmir, Antalya ve Muğla illerinde faaliyet gösteren A grubu se- 
yahat acentalarının yöneticileri oluşturmaktadır. Evreni belirlemek üzere TÜRSAB resmi web sayfası kullanılmıştır. TÜRSAB 2016 yılı verilerine göre İstanbul'da 2964, İzmir'de 385, Antalya'da 1266 ve Muğla'da 637 olmak üzere toplam 5252 A grubu seyahat acentası bulunmaktadır.

Araştırmanın örneklemini ise İstanbul, İzmir, Antalya ve Muğla illerinde faaliyet gösteren, en az bir ya da daha fazla yabancı çalışanı olan A grubu seyahat acentalarının Türk ve yabancı yöneticileri oluşturmaktadır. Yapılan araştırmalarda Yapısal Eşitlik Modeli'nde seçilecek örneklem hacminin 200-500 arasında olması gerektiği belirtilmektedir (Kline 1994: 111). Bu doğrultuda araştırmanın örneklem büyüklüğü 350 olarak belirlenmiştir.

\section{Anket Hazırlama ve Veri Toplama}

Kolayda örnekleme yöntemi kullanılarak, yaban$\mathrm{Cl}$ çalışanların çoğunluğunun istihdam edildiği bu illerde, A grubu seyahat acentalarında çalışan Türk ve yabancı 350 yöneticiden anket tekniğiyle veri elde edilmiştir. Anketi cevaplayan $40 \mathrm{ki}$ şinin geçersiz form doldurmaları nedeniyle 310 kişiden elde edilen veriler kullanılabilir nitelikte olmuştur.

Araştırmada, anket formunun hazırlanması için detaylı yazın incelemeleri yapılmış, önceden yapılmış çalışmalar incelenmiş ve elde edilen bilgiler ışığında araştırmanın yapısal modeli ile uyumlu hale getirilerek anket formu oluşturulmuştur. Kültürel farklılıkların yönetimi ile ilgili ölçek, Akiş (2007) tarafından yapılan 'Farklı Kültürlerde Liderlik Yapmak' adlı çalışmadan uyarlanmıştır. Kültürel zekâ düzeyini ölçmeyi amaçlayan ikinci ölçek ise Ang vd. (2007) tarafından yapilan 'Cultural Intelligence: Its Measurement and Effects on Cultural Judgment and Decision Making, Cultural Adaptation, and Task Performance' adlı çalışmada geliştirilen ölçekten uyarlanmıştır.

Araştırmada verilerin toplanmasında kullanılan anket formu üç kısımdan oluşmaktadır. İlk kısımda, kültürel zekâ düzeyini ölçmeye yönelik 20 maddelik Kültürel Zekâ Ölçeği kullanılmıştır. Ölçeğin Türkçe çevirisi yazında bulunmadığından, orijinalinden çeviri yapıldıktan sonra, ilk aşamada dil uzmanı üç kişiye kontrol ettirile- rek orijinal dilindeki anlamı ifade edip etmediği kontrol edilmiştir. Daha sonra, ölçeğin açıklığı ve çevirinin anlaşılırlığını ölçmek için öncelikle beş akademisyene sonrasinda ise 50 farklı A grubu seyahat acentası yöneticisine anketteki ifadeler kontrol ettirilmiştir. Ön kontroller sonucunda ankette belirtilen ifadelerin katılımclar tarafından anlaşıldığı ve yanıtlandığ Kontrol aşamasından sonra ölçek uygulanmaya hazır hale getirilmiştir. İkinci kısımda, kültürel farklılıkların yönetimi ile ilgili söz konusu ölçeğin orijinalinden, araştırma amacına uygun olan toplam 16 ifade alınarak çalışmada kullanılmıştır. Anketin ilk iki kısmındaki ifadeler için 5 'li Likert-tipi yanıtlar hazırlanmıştır. Birinci ölçekte; '1- Kesinlikle Katılmıyorum' ve '5- Kesinlikle Katılıyorum' yargılarına denk gelmektedir. İkinci ölçekte ise; '1- En güçlü özelliğimdir' ve '5Var olmayan özelliklerimden biridir' yargılarına denk gelmektedir. Anket formunun üçüncü kısminda ise örneklemin özelliklerini belirlemeye yönelik 14 adet soruya yer verilmiştir.

\section{Güvenilirlik ve Geçerlilik}

Araştırmada veri toplama aracı olarak kullanılan anket formunda yer alan ölçeklerin hangi düzeyde güvenilir olduğunu tespit etmek üzere, ölçeklerin güvenilirlikleri Cronbach's Alpha (Alfa Katsayısı) istatistiği ile test edilmiştir. Ankette yer alan ölçeklerin güvenilirlikleri, her bir boyut için ve tüm ölçek için test edilmiş ve tüm ölçekler güvenilir bulunmuştur. Güvenilirliğin bir ölçüsü olarak Cronbach's Alpha istatistiği seçilmiş ve Cronbach's Alpha istatistiğinin 0,764 ile 0,95 arasında değiştiği belirlenmiş̧tir. Sonrasında soru bütün korelasyonlara (corrected item-total correlation) bakılmış ve negatif korelasyona sahip maddeye rastlanmamıştır. Ayrıca ölçeklerden çıkarıldığında güvenilirliği anlamlı bir şekilde arttıran bir maddeye de rastlanmamıştır. Dolayısıyla, ölçeklerde yer alan tüm ifadelerin gerekli olduğuna karar verilmiştir.

Madde ortalamalarının eşit olup olmadığı, diğer bir deyişle ifadelerin yöneticiler tarafından aynı yaklaşım ile algılanıp algılanmadığ 1 Hotelling's T2 ile araştırılarak, tüm ölçeklerde anlamlı bulunmuş ve tüm ifadelerin benzer so- 
Tablo 2. Kültürel Zekâ ve Kültürel Farklılıkların Yönetimi Ölçeklerindeki İfadelerin Betimleyici İstatistikleri ve Güvenilirlik Analizi Sonuçları

\begin{tabular}{|c|c|c|c|c|c|c|c|}
\hline Ortalama & $\begin{array}{c}\text { Std. } \\
\text { Sapma }\end{array}$ & $\begin{array}{l}\text { Soru bütün } \\
\text { korelasyon }\end{array}$ & $\begin{array}{c}\text { Silindiğinde } \\
\text { Cronbach's } \\
\text { Alpha }\end{array}$ & Ortalama & $\begin{array}{c}\text { Std. } \\
\text { Sapma }\end{array}$ & $\begin{array}{l}\text { Soru bütün } \\
\text { korelasyon }\end{array}$ & $\begin{array}{c}\text { Silindiğinde } \\
\text { Cronbach's } \\
\text { Alpha }\end{array}$ \\
\hline
\end{tabular}

\begin{tabular}{|c|c|c|c|c|c|c|c|c|c|}
\hline \multirow{2}{*}{\multicolumn{5}{|c|}{$\begin{array}{l}\text { Uluslararası İş Bilgisi: Cronbach's Alpha=,905 } \\
\text { Ölçek ortalama }=3,225 \text { Hotelling's } T^{2}=96,51 p=0,0001\end{array}$}} & \multicolumn{5}{|c|}{ Üst bilişsel Zekâ: Cronbach's Alpha=,828 } \\
\hline & & & & & \multicolumn{5}{|c|}{ Ölçek ortalama $=3,80$ Hotelling's $T^{2}=122,12 p=0,0001$} \\
\hline UAIB1 & 3,27 & 1,084 & 790 & 879 & UB1 & 4,04 & ,703 & ,707 & ,761 \\
\hline UAIB2 & 3,37 & ,952 & ,848 & ,855 & UB2 & 3,65 & 798 & ,646 & ,789 \\
\hline UAIB3 & 2,93 & 991 & ,666 & 919 & UB3 & 3,77 & ,635 & ,700 & ,770 \\
\hline UAIB4 & 3,33 & 875 & 867 & 853 & UB4 & 3,74 & ,812 & ,595 & ,815 \\
\hline \multicolumn{5}{|c|}{ Kültürel Adaptasyon: Cronbach's Alpha=,886 } & \multicolumn{5}{|c|}{ Bilişsel Zekâ: Cronbach's Alpha=,764 } \\
\hline \multicolumn{5}{|c|}{ Ölçek ortalama $=3,43$ Hotelling's $T^{2}=121,81 p=0,0001$} & \multicolumn{5}{|c|}{ Ölçek ortalama $=3,60$ Hotelling's $T^{2}=83,125 p=0,0001$} \\
\hline KA1 & 3,25 & 1,053 & ,772 & ,851 & B2 & 3,69 & ,903 &, 581 & ,701 \\
\hline KA2 & 3,71 & ,858 & ,724 & ,864 & B4 & 3,33 & ,886 &, 535 & ,752 \\
\hline KA3 & 3,40 & 929 & ,830 & ,822 & B6 & 3,75 & ,812 & 681 &, 594 \\
\hline KA4 & 3,35 & ,784 & ,706 & 872 & & & & & \\
\hline \multicolumn{5}{|c|}{ Farklı Perspektiflerden Bakabilme: Cronbach's Alpha=,926 } & \multicolumn{5}{|c|}{ Motivasyonel Zekâ: Cronbach's Alpha=,891 } \\
\hline \multicolumn{5}{|c|}{ Ölçek ortalama $=3,62$ Hotelling's $T^{2}=49,91 p=0,0001$} & \multicolumn{5}{|c|}{ Ölçek ortalama $=3,95$ Hotelling's $T^{2}=320,41 p=0,0001$} \\
\hline FPB1 & 3,64 & 1,277 & ,865 & ,894 & M1 & 4,25 & ,777 & ,733 & ,867 \\
\hline FPB2 & 3,81 & 1,175 & ,835 & ,902 & M2 & 4,18 & 687 & 746 & ,867 \\
\hline FPB3 & 3,50 & 1,184 & ,815 & 909 & M3 & 3,84 & ,733 & 679 & 879 \\
\hline \multirow[t]{2}{*}{ FPB4 } & 3,54 & 944 & ,831 & 910 & M4 & 3,74 & ,921 & 809 & ,851 \\
\hline & & & & & M5 & 3,73 & ,869 & ,730 & ,869 \\
\hline \multicolumn{5}{|c|}{ Yenilikçi Olma: Cronbach's Alpha=,911 } & \multicolumn{5}{|c|}{ Davranışsal Zekâ: Cronbach's Alpha=, 834} \\
\hline \multicolumn{5}{|c|}{ Ölçek ortalama $=3,30$ Hotelling's $T^{2}=13,32 p=0,002$} & \multicolumn{5}{|c|}{ Ölçek ortalama $=3,67$ Hotelling's $T^{2}=180,45 p=0,0001$} \\
\hline YO1 & 3,24 & ,792 & 798 & 891 & D1 & 3,57 & 1,070 & 677 & ,788 \\
\hline YO2 & 3,36 & 873 & ,819 & 877 & D3 & 4,16 &, 557 & ,435 & 878 \\
\hline \multirow[t]{2}{*}{ YO3 } & 3,30 & 799 & ,852 & 847 & D4 & 3,56 & ,936 & ,824 & 716 \\
\hline & & & & & D5 & 3,40 & 1,121 & ,804 & ,723 \\
\hline
\end{tabular}

Kültürel Farklılıkların Yönetimi: Cronbach's Alpha=,943 Ölçek ortalama $=3,40$ Hotelling's $T^{2}=279,443 p=0,0001$
Kültürel Zekâ: Cronbach's Alpha=,915

Ölçek ortalama $=3,775$ Hotelling's $T^{2}=647,844 p=0,0001$ 
nuçlar verecek şekilde hazırlanmış olduğu görülmüştür. Ölçeklerin, ölçek ortalamalarına da bakılmış ve 3,22 ile 3,95 arasında değiştiği saptanmıştır. Ölçeklerde yer alan ifadelerin güvenilirlik analizi sonuçları ve betimleyici istatistikler Tablo 2'de verilmiştir.

Araştırmada kullanılan ölçeklerin güvenirliklerine ilişkin $\alpha$ katsayıları Tablo 2'de belirtilmiştir. Bu hususta, öncelikle kültürel zekâ ifadelerini içeren ölçeğin güvenilirlik katsayıları incelenmiştir $(\alpha=0,915)$. Kültürel farklılıkların yönetimi ile ilgili ölçeğin güvenilirlik katsayıları ise $(\alpha=0,943)$ olarak bulunmuştur. Bu bağlamda, ölçekte yer alan her bir bölümün oldukça güvenilir olduğu görülürken, kullanılan ölçeğin araştırma kriterlerini ölçme açısından yüksek güvenilirlik düzeyinde olduğu görülmektedir $(\alpha=0,95)$.

\section{ANALIZ VE BULGULARIN YORUMLANMASI}

Verilerin analiz edilmesinde "SPSS 16.0" ve "LISREL 8.54" istatistik paket programlarından yararlanılmıştır. Çalışmada kültürel farklılık yönetimi alt boyutları için doğrulayıcı faktör analizi ile ölçeğin alt boyutları doğrulanmıştır. Aynı süreç kültürel zekâ ölçeği için de uygulanmıştır. Araştırma kapsamında incelenen örneklemin özelliklerine ait bulguların frekans analizleri ve yüzde dağılımı Tablo 3'te yer almaktadır.

Tablo 3'teki bilgiler incelendiğinde ankete katılan erkek yöneticilerin sayısının kadın yöneticilere göre fazla olduğu görülmektedir. Yöneticilerin yaş gruplarına ilişkin veriler incelendiğinde 2335 yaş aralığında yer alan grubun ağırlıkta olduğu görülmektedir. Yöneticilerin \%10'u ortaöğretim mezunu, \%28,4'ü ön lisans mezunu, \%57,7'si lisans mezunu ve \%3,9'u lisansüstü mezunudur.

Yöneticilerin uyrukları incelendiğinde $\% 82,6$ 'sının T.C. vatandaşı olduğu, \%17,4'ünün ise diğer uyruklara mensup oldukları bulgulanmiştır. Uyruk olarak diğer grubunda cevap veren yöneticilerin uyrukları, Alman, Amerikan, Avustralyalı, Azeri, Hollandalı, İngiliz ve Rus olarak görülmektedir. Yöneticilerin yönetim kademelerine bakıldığında, \%48,4'ü üst kademe, $\% 51,6$ 's1 orta kademe yöneticilerdir. Orta ve üst kademe yöneticilerin \%53,5'inin daha önce hiç yurt dışı görev tecrübesi olmamıştır. \%28,7'si ilk kez yurt dışında görev yapan yöneticilerden, $\% 17,7^{\prime}$ si ise iki ve daha fazla yurt dışı görev tecrübesine sahip olan yöneticilerden oluşmaktadır.

Kültürel farklılıkların yönetimi sürecinde, kültürel zekânın etkinliğinin araştırıldığı araştırma-

Tablo 3. Örneklemin Özelliklerine Ait Bulgular

\begin{tabular}{|c|c|c|c|}
\hline Özellik & Gruplar & $n$ & $\%$ \\
\hline \multirow[t]{2}{*}{ Cinsiyet } & Kadın & 103 & 33,2 \\
\hline & Erkek & 207 & 66,8 \\
\hline \multirow[t]{3}{*}{ Yaş } & 23-35 Yaş Arası & 194 & 62,6 \\
\hline & 36-48 Yaş Arası & 100 & 32,3 \\
\hline & 49-61 Yaş Arası & 16 & 5,2 \\
\hline \multirow[t]{2}{*}{ Medeni Durum } & Evli & 149 & 48,1 \\
\hline & Bekar & 161 & 51,9 \\
\hline \multirow[t]{4}{*}{ Eğitim } & Ortaöğretim & 31 & 10 \\
\hline & Ön lisans & 88 & 28,4 \\
\hline & Lisans & 179 & 57,7 \\
\hline & Lisansüstü & 12 & 3,9 \\
\hline \multirow[t]{2}{*}{ Uyruk } & $\mathrm{TC}$ & 256 & 82,6 \\
\hline & Diğer* & 54 & 17,4 \\
\hline \multirow[t]{7}{*}{ Uyruk (Diğer*) } & Alman & 10 & 3,2 \\
\hline & Amerikalı & 2 & 0,6 \\
\hline & Avustralyalı & 5 & 1,6 \\
\hline & Azeri & 3 & 1 \\
\hline & Hollandalı & 1 & 0,3 \\
\hline & İngiliz & 12 & 3,9 \\
\hline & Rus & 21 & 6,8 \\
\hline \multirow[t]{4}{*}{ Sektörde Çalışma } & 5 yıldan az & 9 & 2,9 \\
\hline & 5-9 yıl & 112 & 36,1 \\
\hline & $10-15$ yıl & 112 & 36,1 \\
\hline & 15 yıldan fazla & 77 & 24,8 \\
\hline \multirow[t]{4}{*}{ Şu Anki İşletmede Çalışma } & 1 yıldan az & 35 & 11,3 \\
\hline & $1-3$ yıl & 105 & 33,9 \\
\hline & $4-6$ yıl & 103 & 33,2 \\
\hline & 10 yıl ve üzeri & 67 & 21,6 \\
\hline \multirow[t]{2}{*}{ Yönetim Kademesi } & Üst Kademe & 150 & 48,4 \\
\hline & Orta Kademe & 160 & 51,6 \\
\hline \multirow[t]{4}{*}{ Ne Zamandır Yönetici } & 1 yıldan az & 66 & 21,3 \\
\hline & $1-3$ yıl & 110 & 35,5 \\
\hline & $4-6$ yıl & 82 & 26,5 \\
\hline & 10 yıl ve üzeri & 52 & 16,8 \\
\hline \multirow[t]{3}{*}{ Yurtdışı Görev Tecrübesi } & Hiç yok & 166 & 53,5 \\
\hline & İlk defa & 89 & 28,7 \\
\hline & İki ve daha fazla & 55 & 17,7 \\
\hline \multirow[t]{4}{*}{ Yabancı Dil Bilgisi } & Hiç Bilmiyorum & 9 & 2,9 \\
\hline & Bir dil biliyorum & 160 & 51,6 \\
\hline & İki ve daha fazla & 141 & 45,5 \\
\hline & Toplam & 310 & 100 \\
\hline
\end{tabular}


da gizil değişkenler arasında ve gözlenen değişkenler ile gizil değişkenler arasında olabilecek nedensel ilişkileri görebilmek için yapısal eşitlik modelinden (YEM) yararlanılmıştır. YEM ile kültürel zekâ alt boyutlarının kültürel zekânın oluşumuna olan katkıları ortaya konulmaya çalışılmıştır. Bununla birlikte, kültürel farklılıkların yönetimi alt boyutlarının, kültürel farklılıkları yönetme becerisine olan etkisi de incelenmiştir. Kültürel zekânın, kültürel farklılıkların yönetiminde nasıl bir etkiye sahip olduğunu belirlemeye yönelik yapılan yapısal eşitlik modellemesi, ölçekte yer alan ifadelerin bahsi geçen düzeyleri açıklama başarısını ortaya koymaktadır.

Bu kapsamda oluşturulan ilk modele yönelik elde edilen uyum ölçütleri; $\chi 2=1928,97$, $\mathrm{sd}=422$, $\chi 2 / \mathrm{sd}=4,57, \mathrm{P}$-value $=0,00001$, RMSEA $=0,080$, NFI $=0,91$, NNFI $=0,92$, PNFI $=0,83$, CFI $=0,93$, IFI $=0,93$, RFI $=0,91, \mathrm{GFI}=0,90$, RMR $=0,058$ olarak elde edilmiştir. Buna göre uyum ölçütlerinin iyi düzeyde kabul edilebilir bir uyuma sahip olduğu belirlenmiştir.

Verilen uyum ölçütleri değerlendirildiğinde Yılmaz ve Çelik'in (2009) belirttiği uyum ölçütlerine göre, modelin bir bütün olarak kabul edilebilir olduğu görülmektedir. Yapısal modelde gizil değişkenler arasında veya gözlenen değişken ile gizil değişkenler arasındaki korelasyonlara ait en küçük t istatistiği 2,56 değerinden büyük ve istatistiksel açıdan anlamlı bulunmuştur $(\mathrm{p}<0,01)$. Yollara ait ilişki değerleri Şekil 2'de verilmiştir.

Kültürel zekânın, kültürel farklılıkların yönetiminde nasıl bir etkiye sahip olduğunu belirlemeye yönelik oluşturulan ilişkilere ait model Şekil

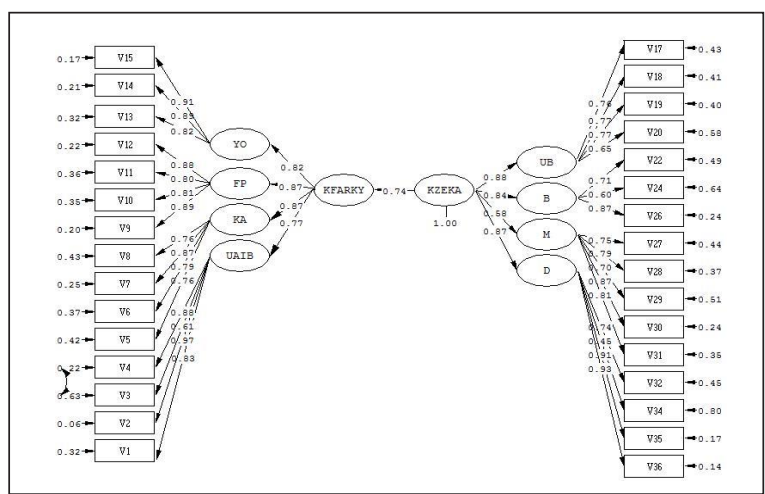

Şekil 2. Kültürel Zekânın, Kültürel Farklıllkların Yönetimine İlişkin Yapısal Model ve İlişki Değerleri 2'de görülmektedir. Şekil 2'deki tüm ilişkiler istatistiksel açıdan anlamlı bulunmuştur. Şekil 2'ye göre;

- Yöneticilerin üst bilişsel zekâ kullanımı gizil değişkeni ile kültürel zekânın oluşumu gizil değişkeni arasında aynı yönde 0,88 birimlik bir ilişki bulunmuştur ( $t=12,86 \mathrm{p}<0,01)$. Yöneticilerin üst bilişsel zekâ kullanımında gerçekleşen bir birimlik artış, kültürel zekânın oluşumunda 0,88 birimlik bir artışa neden olduğundan $\mathrm{H}_{1}$ hipotezi desteklenmiştir.

- Yöneticilerin bilişsel zekâ kullanımı gizil değişkeni ile kültürel zekânın oluşumu gizil değişkeni arasında aynı yönde 0,84 birimlik bir ilişki bulunmuştur $(t=11,35 \mathrm{p}<0,01)$. Yöneticilerin bilişsel zekâ kullanımında gerçekleşen bir birimlik artış, kültürel zekânın oluşumunda 0,84 birimlik bir artışa neden olduğundan $\mathrm{H}_{2}$ hipotezi desteklenmiştir.

- Yöneticilerin motivasyonel zekâ kullanımı gizil değişkeni ile kültürel zekânın oluşumu gizil değişkeni arasında aynı yönde 0,58 birimlik bir ilişki bulunmuştur $(t=8,84 \mathrm{p}<0,01)$. Yöneticilerin motivasyonel zekâ kullanımında gerçekleşen bir birimlik artış, kültürel zekânın oluşumunda 0,58 birimlik bir artışa neden olduğundan $\mathrm{H}_{3}$ hipotezi desteklenmiştir.

- Yöneticilerin davranışsal zekâ kullanımı gizil değişkeni ile kültürel zekânın oluşumu gizil değişkeni arasında aynı yönde 0,87 birimlik bir ilişki bulunmuştur ( $t=12,81 \mathrm{p}<0,01)$. Yöneticilerin davranışsal zekâ kullanımında gerçekleşen bir birimlik artış, kültürel zekânın oluşumunda 0,87 birimlik bir artışa neden olduğundan $\mathrm{H}_{4}$ hipotezi desteklenmiştir.

- Yöneticilerin uluslararası iş bilgisine sahip olması gizil değişkeni ile kültürel farklılıkların yönetimi gizil değişkeni arasında aynı yönde 0,77 birimlik bir ilişki bulunmuştur ( $\mathrm{t}=11,30$ $\mathrm{p}<0,01)$. Yöneticilerin uluslararası iş bilgisine sahip olmasında gerçekleşen bir birimlik artışın, kültürel farklılıkların yönetimi gizil değişkenini 0,77 birim güçlendirdiği bulunmuştur. Dolayısıyla $H_{5}$ hipotezi desteklenmiştir.

- Yöneticilerin kültürel adaptasyonunun güçlü olması gizil değişkeni ile kültürel farklılıkların 
yönetimi gizil değişkeni arasında aynı yönde 0,87 birimlik bir ilişki bulunmuştur ( $\mathrm{t}=11,60$ $\mathrm{p}<0.01)$. Yöneticilerin kültürel adaptasyonlarında gerçekleşen bir birimlik artışın, kültürel farklılıkların yönetimi gizil değişkenini 0,87 birim güçlendirdiği bulunmuştur. Dolayısıyla $H_{6}$ hipotezi desteklenmiştir.

- Yöneticilerin farklı perspektiflerden bakabilme becerilerinin olması gizil değişkeni ile kültürel farklılıkların yönetimi gizil değişkeni arasında aynı yönde 0,87 birimlik bir ilişki bulunmuştur $(t=13,20 \mathrm{p}<0,01)$. Yöneticilerin farklı perspektiflerden bakabilme becerilerinde gerçekleşen bir birimlik artış, kültürel farklılıkların yönetimi gizil değişkenini 0,87 birim güçlendirmektedir. Dolayısıyla $\mathrm{H}_{7}$ hipotezi desteklenmiştir.

- Yöneticilerin yenilikçi olma becerileri gizil değişkeni ile kültürel farklılıkların yönetimi gizil değişkeni arasında aynı yönde 0,82 birimlik bir ilişki bulunmuştur ( $t=11,77 \mathrm{p}<0,01)$. Yöneticilerin yenilikçi olma becerilerinde gerçekleşen bir birimlik artışın, kültürel farklılıkların yönetimi gizil değişkenini 0,82 birim güçlendirdiği bulunmuştur. Dolayısıyla $H_{8}$ hipotezi desteklenmiştir.

- Yöneticilerin kültürel zekâları ile kültürel farklılıkları yönetme becerileri arasında aynı yönde 0,74 birimlik bir ilişki bulunmuştur $(9,48$ $p<0,01)$. Dolayısıyla, yöneticilerin kültürel zekâları artarken kültürel farklılıkları yönetme becerileri de artmaktadır ve $H_{9}$ hipotezi desteklenmiştir. İki gizil değişken arasındaki Yapısal Regresyon Modeli ise;

KFARKY $=0,75^{*}$ KZEKA, Errorvar. $=0,46, \mathrm{R}^{2}=$ 0,55 şeklinde yazılabilir. Yazılan bu regresyon modeline göre; yöneticilerin kültürel zekâlarının, kültürel farklılıkları yönetme becerilerindeki varyansın (değişimin) 0,55'ini açıkladığı ifade edilebilir.

Kültürel zekânın alt boyutları ile kültürel farklılıkların yönetimi alt boyutları arasında pozitif yönlü doğrudan ilişkiler var olabileceğinden, alt boyutlar arasındaki ilişkiler de araştırılmıştır (Tablo 4). Bu kapsamda, yöneticilerin üst bilişsel zekâ kullanımı gizil değişkeni ile kültürel farklılıkların yönetiminin bir alt boyutu olan yöne- ticilerin uluslararası iş bilgisine sahip olmaları gizil değişkeni arasındaki ilişkiyi görebilmek için oluşturulan hipotez 10;

H10: Yöneticilerin üst bilişsel zekâ kullanımı arttıkça, uluslararası iş bilgisine sahip olma becerileri de güçlenir şeklinde kurulmuştur. YEM sonucunda, yöneticilerin üst bilişsel zekâ kullanımı ile uluslararası iş bilgisine sahip olma becerileri arasında aynı yönde 0,54 birimlik bir ilişki bulunmuş ve $H_{10}$ hipotezi desteklenmiştir $(\mathrm{t}=8,68 \mathrm{p}<0,01)$. Dolay1sıyla, yöneticilerin üst bilişsel zekâ kullanımı arttıkça, uluslararası güçlü iş bilgisine sahip olma becerileri de güçlenir bulgusuna ulaşılmaktadır. Aynı şekilde yöneticilerin bilişsel zekâ kullanımı gizil değişkeni ile farklı perspektiflerden bakabilme becerileri arasındaki ilişkiyi görebilmek için oluşturulan hipotez 11;

H11: Yöneticilerin bilişsel zekâ kullanımı arttıkça, farkl perspektiflerden bakabilme becerileri de gü̈çlenir şeklinde kurulmuştur. YEM sonucunda, yöneticilerin bilişsel zekâ kullanımı ile farklı perspektiflerden bakabilme becerileri arasında da aynı yönde 0,59 birimlik bir ilişki bulunmuş ve $H_{11}$ hipotezi desteklenmiştir $(\mathrm{t}>2,56 \mathrm{p}<0,01)$. Kültürel zekânın bir diğer alt boyutu olan motivasyonel zekâ kullanımı gizil değişkeni ile yöneticilerin kültürel adaptasyon becerileri arasındaki ilişkiyi görebilmek için oluşturulan hipotez 12;

H12: Yöneticilerin motivasyonel zekâ kullanımı arttıkça, kültürel adaptasyon becerileri de güçlenir şeklinde kurulmuştur. Yöneticilerin motivasyonel zekâ kullanımları ile kültürel adaptasyon becerileri arasında aynı yönde 0,43 birimlik bir ilişki bulunarak oluşturulan yapısal model anlamlı bulunmuştur. Dolayısıyla $H_{12}$ hipotezi desteklenmiştir $(t>2,56 p<0,01)$. Son olarak, yöneticilerin davranışsal zekâ kullanımındaki artışın, yenilikçi olma becerilerini güçlendirip güçlendirmediğini belirlemeye yönelik model araştırılmıştır. Yapısal model için oluşturulan hipotez 13;

$H_{13:}$ Yöneticilerin davranışsal zekâ kullanımı arttıkça, yenilikçi olma becerileri de güçlenir şeklinde kurulmuştur. Yöneticilerin davranışsal zekâ kullanımı ile yenilikçi olma becerileri arasında da aynı yönde 0,48 birimlik bir ilişki bulunarak $H_{13}$ hipotezi desteklenmiştir $(\mathrm{t}>2,56 \mathrm{p}<0,01)$. Diğer bir ifadeyle, yöneticilerin davranışsal zekâ kullanımı 
Tablo 4. Kültürel Zekâ Alt Boyutları ile Kültürel Farklılıkların Yönetimi Alt Boyutları Arasındaki İlişkilere Ait Uyum Ölçütleri

\begin{tabular}{|c|c|c|c|c|c|c|c|}
\hline MODEL & $x^{2}$ & $x^{2} / s d$ & RMSEA & $\mathrm{NFI}$ & NNFI & CFI & GFI \\
\hline $\mathrm{UB} \Rightarrow \mathrm{UAIB}$ & 55,70 & 3,27 & 0,086 & 0,97 & 0,97 & 0,98 & 0,96 \\
\hline${ }_{\mathrm{B}} \Rightarrow \mathrm{FP}$ & 29,55 & 2,46 & 0,069 & 0,98 & 0,98 & 0,99 & 0,97 \\
\hline $\mathrm{M} \Rightarrow \mathrm{KA}$ & 92,49 & 3,69 & 0,093 & 0,96 & 0,95 & 0,97 & 0,94 \\
\hline $\mathrm{D} \Rightarrow \mathrm{ro}$ & 30,67 & 2,55 & 0,071 & 0,98 & 0,98 & 0,99 & 0,97 \\
\hline
\end{tabular}

arttıkça yenilikçi olma becerileri de güçlenmektedir.

Söz konusu istatistiki bulgular A grubu seyahat acentalarında çalışan yerli ve yabancı yöneticiler için, kültürel farklılıkları yönetme sürecinde kültürel zekânın önemli bir etken olduğunu göstermektedir. Öyle ki, kültürel zekânın dört bileşeni olan üst bilişsel, bilişsel, motivasyonel ve davranışsal zekânın kültürel farklılıkların yönetimi ve onun alt bileşenleri (uluslararası iș bilgisine sahip olma, kültürel adaptasyon, farklı perspektiflerden bakabilme ve yenilikçi olma) ile pozitif yönde bir ilişki içerisinde olduğu bulgulanmıştır. Başka bir ifadeyle, turizm sektörünün kültürlerarası yapısı gereği yöneticilerin kültürel farklılıkları yönetmek adına sahip oldukları kültürel zekâ düzeylerinin üst seviyede olması, kültürlerarası yönetsel başarı için önemli bir koşuldur.

\section{SONUÇ VE TARTIŞMA}

Bu çalışma, A grubu seyahat acentası yöneticilerinin çalışma ortamındaki kültürel farklılıklara yönelik yönetim becerilerinin çeşitli boyutlarını ortaya çıkarmak ve bu farklılıkların yönetimi sürecine, yöneticilerin kültürel zekâ düzeylerinin bir etkisinin olup olmadığını incelemek amacıyla gerçekleştirilmiştir. Çalışmada, YEM kullanılarak, kültürel zekânın kültürel farklılıkların yönetimi sürecinde stratejik bir öneme sahip olduğu bulgulanmıştır. Yapılan analizler sonucunda, önerilen modelin geçerli ve önemli bir açıklama gücüne sahip olduğu söylenebilmekle birlikte, yöneticilerin kültürel zekâ düzeyi ile kültürel farklılıkları yönetme becerileri arasında pozitif yönlü bir ilișki belirlenmiştir. Bu sonuç, kültürlerarası ortamda çalışan yöneticilerin sahip olduk- ları kültürel zekâ düzeylerinin, kültürel farklılıkları yönetme becerilerini de önemli derecede etkilediğini göstermesi açısından önemlidir.

Kültürel zekânın alt boyutları ile kültürel farklılıkların yönetimi alt boyutlarında doğrudan ilişkiler var olabileceğinden, boyutlar arası ilişkiler de araştırılmıştır ve yöneticilerin üst bilişsel, bilişsel, motivasyonel ve davranışsal kültürel zekâsının uluslararası güçlü iş bilgisine sahip olma, farklı perspektiflerden bakabilme, kültürel adaptasyon ve yenilikçi olma becerilerine olumlu bir etkisinin olduğu saptanmıştır. Üst bilişsel kültürel zekâ düzeyinin uluslararası güçlü iş bilgisine sahip olma becerisi üzerine etkisi, bilişsel kültürel zekâ düzeyinin farklı perspektiflerden bakabilme becerisi üzerine etkisi, motivasyonel kültürel zekâ düzeyinin kültürel adaptasyon becerisi üzerine etkisi ve davranışsal kültürel zekâ düzeyinin yenilikçi olma becerisi üzerine etkisi bulgulanmıştır. Nitekim Ang vd.'nin (2007) yapmış olduğu çalışmada da kültürel zekânın karar verme süreçlerinde yöneticiler açısından önemli bir etken olduğu sonucuna varılmıştır. Öte yandan Ersoy'un (2014) yapmış olduğu çalışmada da kültürel zekânın liderlik üzerinde pozitif bir etki yarattığı belirtilmektedir. Yazında yine pek çok yazar kültürel zekânın; kültürel farklılıkların yönetimi, liderlik, karar verme süreçleri, kültürel adaptasyon, kültürel muhakeme gibi özellikle yönetsel konularda önemli bir beceri olduğunu ifade etmektedir (Hofstede 1980; Earley ve Mosakowski 2004; The GLOBE Study House vd. 2004; Ang vd. 2007; Rose vd. 2008; Ramalu vd. 2011; Ng vd. 2012; Bücker vd. 2015; Livermore 2015). Bu bağlamda, çalışmanın sonuçları yazında belirtilen sonuçlar ile paralellik göstermektedir.

Kültürel zekânın turizm sektöründeki etkisine dair nicel bir çalışmanın olmaması, turizm sektörü bağlamında bir karşılaştırma yapılabilmesine olanak vermemektedir. Ancak, turizm sektöründe kültürel zekânın yönetsel bir beceri ve kültürel farklılıkların yönetiminde etkin bir unsur olduğu da çalışmanın temel çıktısı olarak yazına katkı sağlayacaktır. Böylelikle konunun turizm bağlamında tartışmaya açılması da sağlanmış olacaktır.

Bu çalışma, kültürel zekâ konusunun ulusal yazın açısından yeni bir konu olması ve yapısal 
eşitlik modeli ile araştırma verilerinin incelenmesi açısından gelecek çalışmalara örnek oluşturmaktadır. Bununla birlikte, kültürel zekâ kavramının ulusal ve uluslararası yazında turizm boyutunun detaylı bir incelemesinin yapılmamış olması da gelecek çalışmalar için başlangıç noktası olabilecektir. Araştırma bulguları İstanbul, İzmir, Antalya ve Muğla illeri ile sınırlı olup, Türkiye genelinde yapılamadığından, elde edilen sonuçlar ulusal düzeyde bir genelleme yapilabilmesini engellemektedir. Bu nedenle bundan sonra yap1lacak çalışmalarda daha büyük örneklem kitleleri ile farklı bulgulara ulaşılabilecektir. Kültürel farklılıkların yönetilmesinde kültürel zekânın etkisini daha net verilerle ölçmek açısından, farklılık yönetimi uygulamalarına yoğun biçimde sahip olan işletmelerin belirlenmesi ve örnek olay incelemesi kapsamında bir araştırma yapılması yine öneriler arasında yer almaktadır. Yapılacak olan çalışmalar farklı nitel ve nicel araştırma yöntemleri ile desteklenerek sonuçlar arası karşılaştırmalar ile alanyazın zenginleşebilecektir.

\section{KAYNAKÇA}

Akiş, Y. T. (2007). Farklı Kültürlerde Liderlik Yapmak, 16. Kalite Kongresi, 12-14 Kasım. İstanbul.

Ang, S., Van Dyne, L., Koh, C., Ng, K., Templer, K., Tay, C. ve Chandrasekar, N.A. (2007). Cultural İntelligence: Its Measurement and Effects on Cultural Judgment and Decision Making, Cultural Adaptation, and Task Performance, Management and Organization Review, 3 (3): 335-371.

Ang, S. ve Van Dyne, L. (2008). Handbook of Cultural Intelligence : Theory, Measurement, and Applications. Armonk, N.Y.: M.E. Sharpe.

Arora, P. ve Rohmetra, N. (2010). Cultural Intelligence: Leveraging Differences to Bridge the Gap in the International Hospitality Industry, International Review of Business Research Papers, 6 (5): 216-234.

Barutçugil, İ. (2011). Kültürler Arası Farklılıkların Yönetimi. İstanbul: Kariyer Yayıncilik.

Bücker, J., Furrer, O. ve Lin, Y. (2015). Measuring Cultural Intelligence (CQ): A New Test of the CQ Scale, International Journal of Cross Cultural Management, 15 (3): 259-284.

Dursun, Y. ve Kocagöz, E. (2010). Yapısal eşitlik modellemesi ve regresyon: Karşılaştırmalı bir analiz, Erciyes Üniversitesi İktisadi ve İdari Bilimler Fakültesi Dergisi, 35: 1-17.

Earley, P. C. ve Ang, S. (2003). Cultural Intelligence: Individual Interactions Across Cultures. Stanford, Calif: Stanford Üniversitesi Yayınları.

Earley, P. C. ve Mosakowski, E. (2004). Cultural Intelligence, Harvard Business Review, 82 (10): 139-146.
Earley, P. C. ve Peterson, R. (2004). The Elusive Cultural Chameleon: Cultural Intelligence as a New Approach to Intercultural Training for the Global Manager, Academy of Management Learning \& Education, 3 (1): 100-115.

Ehtiyar, R. (2003). Kültürel Sinerji: Uluslararası İşletmelere Yönelik Kavramsal Bir İrdeleme, Akdeniz İ̈BF Dergisi, (5): 66-78.

Ersoy, A. (2014). The Role of Cultural Intelligence in CrossCultural Leadership Effectiveness: A Qualitative Study in the Hospitality Industry, Journal of Yasar University, 9 (35): 6099-6108.

Gibson, C. B. ve Dibble, R. (2008). Culture Inside and Out: Developing a Collaboration's Capacity to Externally Adjust. İçinde; S. Ang, ve L. Van Dyne (Editörler) Handbook of Cultural Intelligence: Theory, Measurement, and Applications (ss. 221-240). Armonk, New York: M. E. Sharpe.

Gümüş, M. (2009). İşletmelerde Farklılıkların Yönetimi. İstanbul: MKM.

House, R. J., Hanges, P. J., Javidan, M., Dorfman, P. W. ve Gupta, V. (2004). Culture, Leadership, and Organizations: The GLOBE Study of 62 Societies. Londra: Sage Yayınları.

Hofstede, G. (1980). Culture's Consequences and International Differences in Work Related Values. Londra: Sage Yayınlar1.

İşçi, E., Söylemez, Ö. ve Kaptanoğlu Y. A. (2013). Örgütlerde Kültürel Zekâ ve Hastane İşletmelerinde Kültürel Zekâ Düzeyinin Belirlenmesine Yönelik Bir Araştırma, KAU İ̈BF Dergisi, 4 (5): 1-18.

Kim, Y. J. ve Van Dyne, L. (2011). Cultural Intelligence and International Leadership Potential: The Importance of Contact for Members of the Majority, Journal of Applied Psychology, 61 (2): 272-294.

Kline, R. B. (1994). Validity of a Math Skills Pretest for Introductory Statistics, Presented at the 102nd Annual Meeting of the American Psychological Association, Los Angeles.

Livermore, D. (2015). Leading with Cultural Intelligence (İkinci Bask1). New York: AMACOM.

Mollica, K. A. (2003). The Influence of Diversity Context on White Men's and Racial Minorities' Reactions to Disproportionate Group Harm, The Journal of Social Psychology, 14 (4): 415-431.

Nahavandi, A. ve Malekzadeh A. R. (1998). Organizational Behavior. New Jersey: Prentice -Hall.

Ng, K. Y., Van Dyne, L. ve Ang, S. (2012). Cultural Intelligence: A Review, Reflections, and Recommendations for Future Research. İçinde; A. M. Ryan, F. T. L. Leong ve F. L. Oswald (Editörler) Conducting Multinational Research: Applying Organizational Psychology in the Workplace (ss. 29-58). Washington: American Psychological Association.

Özbilgin, M. (2005). 'Global' Diversity Management: The Case of Automobile Manufacturing Companies in Japan, Japan Institute for Labor Policy an Training (Working Paper Series).

Ramalu, S., Wei, C.C. ve Rose, R.C. (2011). The Effects of Cultural Intelligence on Cross-Cultural Adjustment and Job Performance Amongst Expatriates in Malaysia, 
International Journal of Business and Social Science, 2 (9): 59-71.

Rockstuhl, T., Şahin, F., Gürbüz, S. ve Ang, S. (2011). International Military Officer Potential: Cultural Capital and Cultural Intelligence, 53rd International Military Testing Association Conference, Ekim 31 - Kasım 3. Bali, Endonezya.

Rose, R.C., Kumar, N. ve Ramalu, S. (2008). A Review on Individual Differences and Cultural Intelligence, The Journal of International Social Research, 1 (4): 504-522.

Seymen, O. A. (2006). Cultural Diversity Phenomenon in Organisations and Different Approaches for Effective Cultural Diversity Management:A Literary Review, Cross Cultural Management: An International Journal, 13 (4): 296-315.

Şahin, F. (2011). Liderin Kültürel Zekasının Astların Örgütsel Vatandaşlık Davranışı ile İş Doyumu Üzerine Etkisi, Savunma Bilimleri Dergisi, 10 (2): 80-104

Şahin, F., Gürbüz, S., Köksal, O. ve Ercan, Ü. (2012). Kültürel Zekâ, Duygusal Zekâ ve Sosyal Zekâ'dan Farklı mıdır? 11. Ulusal İşletmecilik Kongresi, (ss. 356-365). Konya.

Şimşek, Ö. F. (2007). Yapısal Eşitlik Modellemesine Giriş (Temel ilkeler ve Lisrel Uygulamalari). Ankara: Ekinoks Yayınları.

Templer, K., Tay, C. ve Chandrasekar, A. (2006). Motivational Cultural Intelligence, Realistic Job Preview, Realistic Living Conditions Preview, and Cross-Cultural Adjustment, Group \& Organization Management, 31 (1): 154-173.
Thomas, D.C., Elron, E., Stahl, G., Ekelund, B.Z. Ravlin, R.C. ve Cerdin, J. (2008). Cultural Intelligence: Domain and Assessment, International Journal of Cross Cultural Management, 8 (2): 123-143.

Thomas, D. ve Inkson, K. (2004). Cultural Intelligence: People Skills for Global Business. San Francisco, CA: Berrett-Koehler.

TÜRSAB (2016). 2016 yılı A grubu seyahat acentaları sayısı. http://www.tursab.org.tr/tr/seyahat-acentalari/seyahatacentasi-arama? search $=1$ adresinden alınmıştır, Erişim tarihi: 12 Mart 2016.

Van Dyne, L., Ang, S. ve Livermore, D. (2010). Cultural Intelligence: A Pathway for Leading in a Rapidly Globalizing World. İçinde; K. M. Hannum, B. McFeeters, ve L. Booysen (Editörler) Leading Across Differences: Cases and perspectives (ss. 131-138). San Francisco, CA: Pfeiffer.

Yeşil, S. (2009). Kültürel Farklılıkların Yönetimi ve Alternatif Bir Strateji: Kültürel Zekâ, KMU İ̈BF Dergisi, 11 (16): 100-131.

Yeşil, S. (2010). 21. Yüzyılın Küresel Örgütleri için Kültürel Zeka, Çukurova Üniversitesi Sosyal Bilimler Enstitüsü Dergisi, 19 (2): 147-168.

Yılmaz, V. (2004). Lisrel ile Yapısal Eşitlik Modelleri: Tüketici Şikayetlerine Uygulanması, Anadolu Üniversitesi Sosyal Bilimler Dergisi, 4 (1): 77-90.

Yılmaz, V. ve Çelik, E. H. (2009). Lisrel ile Yapısal Eşitlik Modellemesi-I Temel Kavramlar, Uygulamalar, Programlama. Ankara: Pegem Akademi.
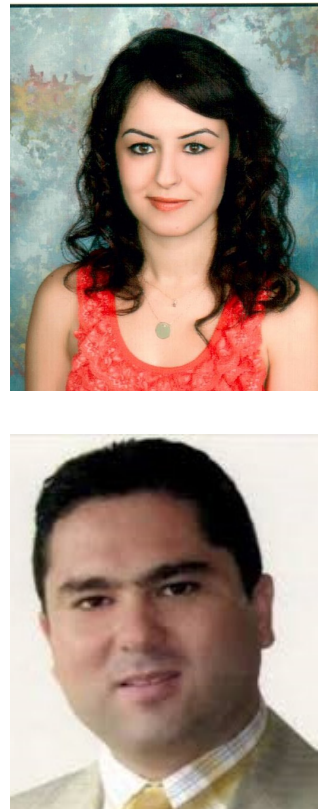

Nur KULAKOĞLU DILEK

Çanakkale Onsekiz Mart Üniversitesi Turizm İșletmeciliği ve Otelcilik Yüksekokulu Seyahat İşletmeciliği Bölümü'nden mezun oldu (2009). Yüksek lisans derecesini Muğla Sıtkı Koçman Üniversitesi Sosyal Bilimler Enstitüsü Turizm İşletmeciliği Anabilim Dalı'ndan (2014) aldı. Muğla Sıtkı Koçman Üniversitesi Sosyal Bilimler Enstitüsü Turizm İşletmeciliği Bölümü'nde Araştırma Görevlisi olarak çalışmaya başladı (2011-2014). Batman Üniversitesi Turizm İşletmeciliği ve Otelcilik Yüksekokulu Turizm ve Otel İșletmeciliği Bölümü'nde Araștırma Görevlisi olarak çalışmaya başladı (2014). Halen Batman Üniversitesi Turizm İșletmeciliği ve Otelcilik Yüksekokulu'nda Araștırma Görevlisi olarak görev yapmaktadır. Temel çalışma alanları Turizm Psikolojisi ve Turizm Sosyolojisi'dir.

\section{Cafer TOPALOĞLU}

Gazi Üniversitesi Ticaret ve Turizm Eğitim Fakültesi Turizm Eğitimi Bölümü'nden mezun oldu (1996). Yüksek lisans derecesini Gazi Üniversitesi'nden Turizm İşletmeciliği Eğitimi anabilim dalından (2000), doktora derecesini de Dokuz Eylül Üniversitesi Turizm Isşletmeciliği Anabilim dalından aldı (2004). Muğla Üniversitesi Turizm İșletmeciliği ve Otelcilik Yüksekokulu'nda araștırma görevlisi olarak çalıştı (2002). Dokuz Eylül Üniversitesi'nde İzmir Meslek Yüksekokulu'nda araştırma görevlisi olarak çalıştı (2002). Doktorasını tamamladıktan sonra, Dokuz Eylül Üniversitesi Sosyal Bilimler Enstitüsü'nde araștırma görevlisi doktor olarak görev aldı (2004). Muğla Üniversitesi Turizm İşletmeciliği ve Otelcilik Yüksekokulu'nda araştırma görevlisi doktor olarak çalışmaya başladı (2004). Muğla Üniversitesi Turizm İşletmeciliği ve Otelcilik Yüksekokulu'nda öğretim görevlisi doktor olarak çalıșmaya bașladı (2004). Muğla Üniversitesi Turizm İsletmeciliği ve Otelcilik Yüksekokulu'nda Yardımcı Doçent Doktor olarak çalışmaya bașladı (2004). Doçentlik unvanını turizm alanında aldı (2012). Halen Muğla Sıtkı Koçman Üniversitesi Turizm Fakültesi'nde Konaklama İşletmeciliği Bölümü'nde görev yapmaktadır. Temel çalıșma alanları; turizm ișletmeciliği ve yönetimdir. 